\title{
Primary cilia in gastrointestinal stromal tumors
}

\author{
J. DVORAK ${ }^{1, *}$, V. SITOROVA², D. HADZI NIKOLOV ${ }^{2}$, A. FILIPOVA ${ }^{3}$, A. RYSKA ${ }^{2}$, B. MELICHAR ${ }^{3}$, I. RICHTER ${ }^{4}$, D. BUKA ${ }^{1}$, J. MOKRY ${ }^{5}$, S. FILIP' ${ }^{1}$, J. PETERA ${ }^{1}$
}

${ }^{1}$ Department of Oncology and Radiotherapy, Charles University Medical Faculty and University Hospital, Hradec Kralove, Czech Republic; ${ }^{2}$ Department of Pathology, Charles University Medical Faculty and University Hospital, Hradec Kralove, Czech Republic; ${ }^{3}$ Department of Medical Biochemistry, Charles University Medical School, Hradec Kralove, Czech Republic; ${ }^{4}$ Department of Oncology, Palacky University Medical Faculty and Teaching Hospital, Olomouc, Czech Republic; ${ }^{5}$ Department of Oncology, Regional Hospital, Liberec, Czech Republic; ${ }^{6}$ Department of Histology and Embryology, Charles University Medical Faculty, Hradec Kralove, Czech Republic

*Correspondence: dvorakj@fnhk.cz

Received February 8, 2013 / Accepted September 18, 2013

\begin{abstract}
The primary cilium is a solitary, sensory, non-motile microtubule-based structure that arises from the centrosome and is projected from the surface of most human cells. The objective of the current pilot study was to conduct an investigation of presence and frequency of cilia in gastrointestinal stromal tumors (GIST).

The presence of primary cilia in GIST was evaluated in 9 patients, including 8 primary tumors and 1 liver metastasis. In 2 patients the presence of primary cilia was evaluated not only in the primary tumor, but also in recurrence: in 1 patient in recurrence without previous treatment with imatinib and in 1 patient in recurrence after treatment with imatinib. The primary cilia of GIST cells were immunofluorescently stained with primary monoclonal anti-acetylated tubulin alpha antibody and cell nuclei with DAPI.

We observed 9985 nuclei of cells of GISTs and 425 primary cilia in total. The median of frequency of primary cilia in cells of GISTs in all examined samples was $4.26 \%$, in primary tumors was $4.32 \%$ and in metastases was $3.64 \%$, respectively.

This pilot study provides the evidence of the presence of primary cilia in GISTs in different organs. Primary cilia were identified in all examined cases of GIST, including primary tumors, metastases and recurrent lesions without and with previous treatment with imatinib.
\end{abstract}

Key words: GIST, primary cilia, imatinib, recurrence

The primary cilium is a solitary, sensory, non-motile microtubule-based structure that arises from the centrosome and is projected from the surface of most human cells. The presence of a primary cilium on the surface of a cell is not permanent, limited to the quiescent $G_{1}\left(G_{0}\right)$ phase and early $S$ phase of the cell cycle. Primary cilia are present on most vertebrae cell types [1].

Primary cilia are active in the sensing of chemical and mechanical signals from the extracellular environment [2]. In primary cilia are present receptors, ion channels and signal pathways specific to the functions of the tissues in which they are located. Primary cilia actively participate in the regulation of platelet derived growth factor (PDGF), epidermal growth factor (EGF), Hedgehog, Wnt and mammalian target of rapamycin signaling pathways, and affect cytosolic calcium fluxes [3].

Primary cilia are firmly interconnected with the cell cycle. In post-mitotic cells, the centrosome, being composed of two centrioles surrounded by pericentriolar material, migrates toward the cell surface, where the mother centriole differentiates into a basal body that nucleates microtubules to cause the occurrence of the primary cilium [4]. Disassembly of the primary cilium precedes cell cycle re-entry, the initiation of DNA synthesis, and mitosis [5]. The association between the ciliary cycle and the cell cycle is, however, not only dependent on availability of centrioles, but also on the active participation of several proteins involved in cell division in the control of ciliogenesis. Conversely: certain ciliary proteins have been reported as directly regulating the cell cycle [3].

Gastrointestinal stromal tumors (GIST), generally driven by oncogenic KIT or platelet-derived growth factor receptor alpha (PDGFR $\alpha$ ) mutations, are the most commonly found mesenchymal tumors in the gastrointestinal tract. GIST are usually found in the stomach (60\%) and small intestine (30\%), 
but may also appear anywhere in the gastrointestinal tract and the intra-abdominal soft tissues. Tumor size and mitotic count are the primary prognostic parameters for GIST which can show spindle cell or epithelioid morphology [6]. Based on the results of prospective trials demonstrating disease control in the majority of the patients, with median survival in responding patients being around 6 years $[7,8]$, imatinib, a tyrosine kinase inhibitor, was established as the therapy of choice for patients with metastatic inoperable GIST [9].

GIST are thought to arise from the interstitial cells of Cajal or their precursor cells. Interstitial cells of Cajal are localised between the two muscular layers of the gastrointestinal tract and are involved in the regulation of peristaltic movements [10]. Primary cilia were observed on the surface of the interstitial cells of Cajal in the rabbit [11], rat duodenum [12] and mouse stomach [13]. The presence of primary cilia in 4 patients with human gastric GIST cells has been already observed in a ultrastructure study [14]. The objective of this study was to investigate the presence and the frequency (quantity) of primary cilia in GISTs in different organs in primary tumors, metastases and recurrent lesions without and with previous treatment with imatinib.

\section{Patients and methods}

Patients. Tumor tissue blocks of 9 patients with GIST, 5 men and 4 women, with a median age 62 (range $41-75$ ) years treated between May 2001 and March 2011 at Charles University Medical School Teaching Hospital's Department of Oncology and Radiotherapy in Hradec Kralove, Czech Republic were examined (Table 1). The anatomical location of primary tumors was as follows: stomach in 4 patients, omentum in 2 patients, jejunum in 1 patient, ileum in 1 patient and sigmoid colon in

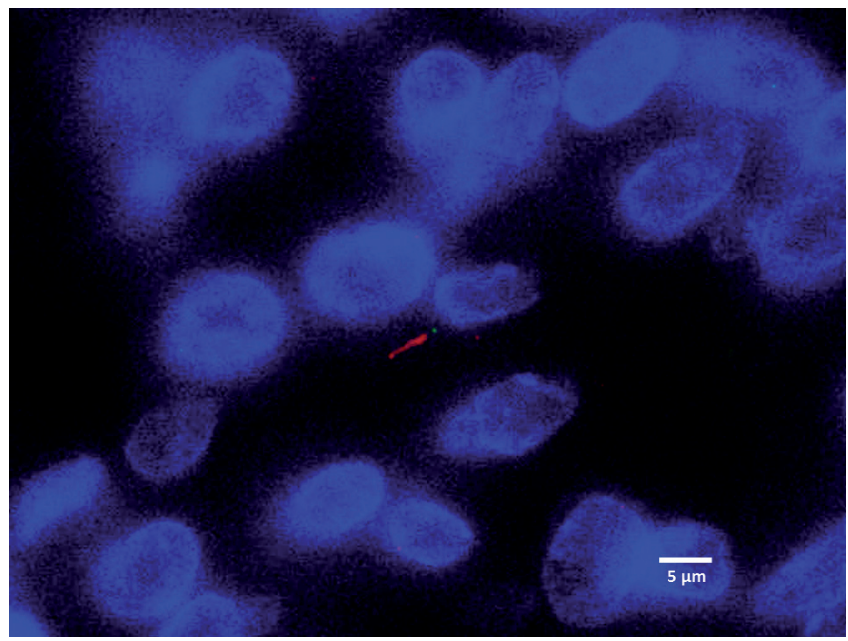

Figure 1. Primary cilium of omentum GIST co-stained for $\gamma$-tubulin (a specific marker of centrosomes) and acetylated $\alpha$-tubulin. Cell nuclei stained with blue DAPI, magnification 100x. Scale bar $5 \mu \mathrm{m}$.

\section{Table 1. Examined GIST}

\begin{tabular}{|c|c|c|c|c|c|}
\hline $\begin{array}{l}\text { Patient } \\
\text { number }\end{array}$ & Location & Age & Sex & $\begin{array}{l}\text { Size } \\
(\mathrm{mm})\end{array}$ & $\begin{array}{l}\text { Mitotic } \\
\text { index }\end{array}$ \\
\hline 1 & stomach & 65 & $\mathrm{~F}$ & 50 & $4 / 50$ \\
\hline 2 & stomach & 80 & M & 63 & $50 / 50$ \\
\hline 3 & $\begin{array}{l}\text { primary tumor } \\
\text { stomach; } \\
\text { PC examined only in } \\
\text { liver metastasis }\end{array}$ & 48 & M & 40 & $50 / 50$ \\
\hline 4 & $\begin{array}{l}\text { stomach } \\
\text { recurrence in liver } \\
\text { after imatinib }\end{array}$ & 73 & $\mathrm{~F}$ & 70 & $20 / 50$ \\
\hline 5 & omentum & 62 & $\mathrm{~F}$ & 95 & $25 / 50$ \\
\hline 6 & omentum & 60 & $\mathrm{~F}$ & 50 & $20 / 50$ \\
\hline 7 & $\begin{array}{l}\text { jejunum } \\
\text { recurrence } \\
\text { in retroperitoneal LN } \\
\text { without imatinib }\end{array}$ & 40 & M & 35 & $40 / 50$ \\
\hline 8 & ileum & 63 & $\mathrm{~F}$ & 110 & $10 / 50$ \\
\hline 9 & $\begin{array}{l}\text { sigmoid } \\
\text { colon }\end{array}$ & 51 & $\mathrm{M}$ & 190 & $30 / 30$ \\
\hline
\end{tabular}

Abbreviations: PC - primary cilia; LN - lymph nodes

1 patient. All patients had a histologically verified GIST with immunohistochemically positive antigen c-KIT and CD-34.

The presence of primary cilia was retrospectively evaluated in GIST in 8 primary tumors and 1 liver metastasis (patient number 3). Moreover, in 2 patients the presence of primary cilia was evaluated not only in the primary tumor, but also in the recurrent lesion: in 1 patient in the recurrence without previous treatment with imatinib (patient number 7) and in 1 patient in the recurrence after treatment with imatinib (patient number 4). This patient was treated with a $400 \mathrm{mg}$ dose of imatinib daily.

Immunofluorescence. For the immunofluorescence detection of primary cilia in formalin-fixed, paraffin-embedded tissues, histological sections were deparaffinised in xylene followed by rehydration, plus antigen retrieval for 40 minutes at $96^{\circ} \mathrm{C}$ in $0.1 \mathrm{M}$ citrate buffer ( $\mathrm{pH}$ adjusted to 6 ). Following light washing, sections were treated with $0.05 \%$ Tween 20 for 5 minutes. This was followed by incubation in blocking solution (1\% goat serum, $0.1 \%$ Triton X-100 in PBS) for 30 minutes. The next step was to incubate the sections in primary antibody (monoclonal anti-acetylated $\alpha$-tubulin antibody produced in mouse, dilution 1:4000, clone 6-11B-1, Sigma-Aldrich) for 60 minutes at room temperature. After washing in PBS, sections were incubated in secondary antibody (Alexa fluor 594 donkey anti-mouse $\operatorname{IgG}(\mathrm{H}+\mathrm{L})$ conjugate, Invitrogen) for 1 hour at room temperature. The samples were gently washed again in PBS, before slices were mounted with mounting medium containing 4',6-diamidino-2-phenylindole (VECTASHIELD Mounting Medium with DAPI, Vector Laboratories) for nuclei labelling. Centrosomes were immunofluorescently stained with anti gamma tubulin (Figure 1). 
Assessment. Samples were evaluated by an immunofluorescent microscope Nikon Eclipse 80i. Twenty photos with camera Quad Scan XC-HR300 with immersion lens, magnification 1000x, were performed of each case. Primary cilia and cell nuclei were counted manually because of the 3-dimensional location of primary cilia and cell nuclei. The percentage of primary cilia on GIST cells was counted as a proportion of primary cilia in cell nuclei.

The mitotic index rate of GIST was expressed as the number of mitoses per 50 high power fields using the $40 \mathrm{x}$ objective (total area $5 \mathrm{~mm}^{2}$ in 50 fields) [15].

\section{Results}

The presence of primary cilia was evaluated in a total of 9985 GIST cells, including 8141 cells in 8 primary tumors and 1844 cells in 3 metastases (Table 2). Primary cilia were observed in all examined GIST including all primary tumors, metastases and recurrence, in patients without or with previous imatinib treatment. In 9985 GIST cell nuclei a total of 425 primary cilia were observed. Thus the mean frequency of primary cilia in GIST cells was 4.26\% (range 1.17-9.62\%). In 8 primary tumors 232 primary cilia were observed in 6386 cell nuclei, with a median frequency of primary cilia GIST cells $4.32 \%$ (range $1.17-9.62 \%$ ). In 3 metastases 143 primary cilia were observed in 3599 cell nuclei, with a median frequency of $3.64 \%$ (range $2.34-5.24 \%$ ). There was no difference in the frequency of primary cilia between GIST in different organs.

At the time of analysis, 8 patients were alive, and 1 patient had died. Median follow-up was 7.8 (range 1.5-11.3) years.

\section{Discussion}

To the best of our knowledge, this study provides the first data about the presence and the frequency of primary cilia on cells of GIST in metastases and recurrence, without or with previous treatment of imatinib.

The frequency of primary cilia has been characterized in several other types of tumors. In the study with the transmission electron microscope, 9481 cells from 74 bone and soft tissue tumors (malignant and benign) were examined [16]. The median frequency of cells with primary cilia was as follows: chondrosarcoma $8.1 \%$, malignant schwannoma 5.9\%, Ewing sarcoma of bone $3.0 \%$, osteosarcoma $2.5 \%$, enchodroma $2.0 \%$ and benign nerve tumors $1.1 \%$ [16]. In the study with immunofluorescent staining of clear cell renal cell carcinoma, using anti-acetylated $\alpha$-tubulin primary monoclonal antibody, the median frequency of tumor cells with primary cilia was $7.8 \%$, whereas the median primary cilia frequency was markedly increased in papillary renal cell carcinoma (43.3\%) [17]. In the study with immunofluorescent staining of breast carcinomas, using anti-acetylated $\alpha$-tubulin primary monoclonal antibody, rare primary cilia $0.03 \%$ were observed in cancer epithelial cells only in the triple-negative breast carcinoma [18]. In comparison with studies in other tumor types, the
Table 2. Frequency of primary cilia in GISTs

\begin{tabular}{|c|c|c|c|c|}
\hline $\begin{array}{l}\text { Patient } \\
\text { number }\end{array}$ & Location & $\begin{array}{c}\text { Number of } \\
\text { cells } \\
\text { with PC } \\
\end{array}$ & $\begin{array}{c}\text { Number } \\
\text { of nuclei } \\
\text { (cells) }\end{array}$ & $\begin{array}{l}\% \text { of cells } \\
\text { with PC }\end{array}$ \\
\hline 1 & stomach & 39 & 596 & 6.54 \\
\hline 2 & stomach & 12 & 1025 & 1.17 \\
\hline 3 & $\begin{array}{l}\text { primary tumor } \\
\text { stomach; } \\
\text { PC examined only } \\
\text { in liver metastasis }\end{array}$ & 92 & 1755 & 5.24 \\
\hline \multirow[t]{2}{*}{4} & $\begin{array}{l}\text { stomach } \\
\text { recurrence }\end{array}$ & 28 & 353 & 7.93 \\
\hline & $\begin{array}{l}\text { in liver } \\
\text { after imatinib }\end{array}$ & 22 & 604 & 3.64 \\
\hline 5 & omentum & 19 & 1175 & 1.62 \\
\hline 6 & omentum & 96 & 998 & 9.62 \\
\hline \multirow[t]{2}{*}{7} & jejunum & 24 & 729 & 3.29 \\
\hline & $\begin{array}{l}\text { recurrence in ret- } \\
\text { roperitoneal LN } \\
\text { without imatinib }\end{array}$ & 29 & 1240 & 2.34 \\
\hline 8 & ileum & 28 & 697 & 4.2 \\
\hline 9 & $\begin{array}{l}\text { sigmoid } \\
\text { colon }\end{array}$ & 36 & 813 & 4.43 \\
\hline Sum & & 425 & 9985 & 4.26 \\
\hline Median & & 32 & 771 & 4.2 \\
\hline
\end{tabular}

Abbreviations: \% - percentage; PC - primary cilia; LN - lymph nodes

median frequency of primary cilia on GIST cells is similar to other sarcomas.

The median frequency of primary cilia in 4 patients with gastric GISTs in the ultrastructure study with transmission electron microscopy was slightly higher than 5\% [14]. The median frequency of primary cilia in 3 patients with gastric GISTs in our immunofluorescent study was $6.54,1.17$ and $7.93 \%$, respectively. Data in the present study with different method are in agreement with previously published report.

As cultured cells enter quiescent phase of the cell cycle, a growing proportion of the population is ciliated [4]. In this study only one case of GIST (patient number 1 with primary tumor in stomach) had a low mitotic index of $4 / 50$, but the frequency of primary cilia of GIST cells in this primary tumor (6.54\%) was comparable with frequency of primary cilia of GIST cells in primary tumors with high mitotic indices (range 1.17-9.62\%). In this study, no correlation was observed between mitotic index and the frequency of primary cilia of cells of GIST.

The presence of primary cilia in primary tumors as well as in the recurrent GIST was examined only in two patients. In both patients the frequency of primary cilia in recurrence decreased in comparison with primary tumor: in patient number 7 it decreased from $3.29 \%$ in the primary tumor in the jejunum to $2.34 \%$ in the recurrence in retroperitoneal lymph nodes, and in patient number 4 it decreased from $7.93 \%$ in the primary tumor in the stomach to $3.64 \%$ in the recurrence in the liver. Primary cilia were observed in recurrence without 
(2.34\% in patient number 7 ) and also with previous treatment of imatinib (3.64\% in patient number 4$)$.

After proof of the presence of primary cilia in GIST, future studies should address the molecular composition of these structures. Primary cilia are composed from approximately 300-500 types of proteins [19]. The biological functions of most of these molecules are currently unknown. Different receptors, ion channels and signal pathways are indentified in primary cilia in different tissues. So far there is no information about the receptors, ion channels or signal pathways that are specific for primary cilia in GIST. Genes and proteins involved in the formation, structure or function of the primary cilia may represent new targets for treatment [19].

In conclusion, primary cilia are present in GIST at a median frequency in $4.26 \%$ of GIST cells. Primary cilia were present in all of the examined GISTs, including primary tumors, metastases and recurrence without and with previous treatment of imatinib.

Acknowledgements: This study was supported by MH CZ-DRO (UHHK, 00179906) and the research project UK-LF HK: PRVOUK P37/06.

\section{References}

[1] SATIR P, PEDERSEN LB, CHRISTENSEN ST. The primary cilium at a glance. J Cell Sci 2010; 123:499-503. http://dx.doi. org/10.1242/jcs.050377

[2] Plotnikova OV, Pugacheva EN, GOLEMIS EA Primary cilia and cell cycle In: Sloboda R editor. Primary cilia, Methods in cell biology, vol 94, Burlington, Massachusetts, USA, Elsevier, 2009: 137-160. http: //dx.doi.org/10.1016/S0091679X(08)94007-3

[3] IRIGOIN F, BADANO JL. Keeping the balance between proliferation and differentiation: the primary cilium. Curr Genomics 2011; 12: 285-297. http: //dx.doi.org/10.2174/ $\underline{138920211795860134}$

[4] PLOTNIKOVA OV, GOLEMIS EA, PUGACHEVA EN. Cell cycle-dependent ciliogenesis and cancer. Cancer Res 2008; 68: 2058-2061. http: //dx.doi.org/10.1158/0008-5472.CAN07-5838

[5] SEELYE ES, NACHURY MV. Constructing and deconstructing roles for the primary cilium in tissue architecture and cancer In: Sloboda R editor. Primary cilia, Methods in cell biology, vol 94, Burlington, Massachusetts, USA, Elsevier, 2009: 300-313.

[6] MIETTINEN M, FURLONG M, SARLOMO-RIKALA M, BURKE A, SOBIN LH, et al. Gastrointestinal stromal tumors, intramural leiomyomas, and leiomyosarcomas in the rectum and anus: a clinicopathologic, immunohistochemical, and molecular genetic study of 144 cases. Am J Surg Pathol 2001; 25: 1121-1133. http: //dx.doi.org/10.1097/00000478-200109000-00002

[7] DEMEMTRI GD, VON MEHREN M, BLANKE CD, VAN DEN ABBEELE AD, EISENBERG B, et al. Efficacy and safety of imatinib mesylate in advanced gastrointestinal stromal tumors. N Engl J Med 2002; 347: 472-480. http: //dx.doi. org/10.1056/NEJMoa020461
[8] VAN OOSTEROM AT, JUDSON I, VERWEIJ J, STROOBANTS S, DONATO DI PAOLA E, et al.; European Organisation for Research and Treatment of Cancer Soft Tissue and Bone Sarcoma Group. Safety and efficacy of imatinib (STI571) in metastatic gastrointestinal stromal tumours: a phase I study. Lancet 2001; 358: 1421-1423. http: //dx.doi. org/10.1016/S0140-6736(01)06535-7

[9] MELICHAR B, KASPAROVA M, KALABOVA H, DVORAK J, HYSPLER R, et al. Intestinal permeability, vitamin A absorption and serum alpha-tocopherol in gastrointestinal stromal tumor patients treated with imatinib. J Nutr Sci Vitaminol (Tokyo) 2010; 56: 347-352. http: //dx.doi. org/10.3177/jnsv.56.347

[10] DUENSING S, DUENSING A: Targeted therapies of gastrointestinal stromal tumors (GIST)--the next frontiers. Biochem Pharmacol 2010; 80: 575-583. http: //dx.doi.org/10.1016/ j.bcp.2010.04.006

[11] JUNQUERA C, MARTINEZ-CIRIANO C, CASTIELLA T, SERRANO P, AZANZA MJ, et al. Immunohistochemical and ultrastructural characteristics of interstitial cells of Cajal in the rabbit duodenum. Presence of a single cilium. J Cell Mol Med 2007; 11: 776-787. http: //dx.doi.org/10.1111/j.15824934.2007.00064.x

[12] Junquera Escribano C, Cantarero Carmona I, LUESMA BARTOLOME MJ, SORIANO-NAVARRO M, MARTINEZCIRIANO C, et al. The primary cilium: A relevant characteristic in interstitial cells of rat duodenum enteric plexus. Histol Histopathol 2011; 26: 461-470.

[13] VANNUCCHI MG, ZIZZO MG, ZARDO C, PIERI L, SERIO R, et al. Ultrastructural changes in the interstitial cells of Cajal and gastric dysrhythmias in mice lacking full-length dystrophin (mdx mice). J Cell Physiol. 2004; 199 (2): 293-309. http: //dx.doi.org/10.1002/jcp.10470

[14] CASTIELLA T, MUÑOZ G, LUESMA MJ, SANTANDER S, SORIANO M, et al. Primary cilia in gastric gastrointestinal stromal tumours (GISTs): an ultrastructural study. J Cell Mol Med 2013; 17 (7): 844-853. http: //dx.doi.org/10.1111/ jcmm. 12067

[15] SOBIN LH, GOSPODAROWICZ MK, WITTEKIND C. TNM Classification of Malignant Tumours, 7th Edition, 2010; John Willey \& Sons Ltd West Sussex, UK.

[16] GANEV GG. Pathological significance of cilia and centrioles in bone and soft tissue tumors. J Orthop Sci 1997; 2: 137-145. http: //dx.doi.org/10.1007/BF02492970

[17] SCHRAML P, FREW IJ, THOMA CR, BOYSEN G, STRUCKMANN K, et al. Sporadic clear cell renal cell carcinoma but not the papillary type is characterized by severely reduced frequency of primary cilia. Mod Pathol 2009; 22: 31-36. http: //dx.doi.org/10.1038/modpathol.2008.132

[18] YUAN K, FROLOVA N, XIE Y, WANG D, COOK L, et al. Primary cilia are decreased in breast cancer: analysis of a collection of human breast cancer cell lines and tissues. J Histochem Cytochem 2010; 58: 857-870. http: //dx.doi. org/10.1369/jhc. 2010.955856

[19] MICHAUD EJ, YODER BK. The primary cilium in cell signaling and cancer. Cancer Res 2006; 66: 6463-6467. http: //dx.doi. org/10.1158/0008-5472.CAN-06-0462 